\title{
Universities as Models of Sustainable Energy-Consuming Communities? Review of Selected Literature
}

\author{
Milad Mohammadalizadehkorde * and Russell Weaver \\ Department of Geography, Texas State University, San Marcos, TX 78666, USA; rcweaver@txstate.edu \\ * Correspondence: m_m785@txstate.edu
}

Received: 15 August 2018; Accepted: 10 September 2018; Published: 12 September 2018

\begin{abstract}
Given the prominent position of academia in sustainability studies and sustainability science, it is natural to want to look to universities as models of (or keepers of knowledge about) sustainable practices-including practices related to energy consumption. Nevertheless, there is a long history of and literature on universities failing to implement their own sustainability initiatives. Apart from typical justifications for implementation failure that include budget constraints and financial infeasibility, one of the main obstacles that consistently keeps universities from achieving their own sustainability-related goals is a lack of enforcement. More precisely, universities tend to codify their sustainability-related goals in non-binding declarations that are voluntary. In that respect, failure to achieve a goal does not result in any sort of formal sanction. As such, universities are free to claim a commitment to sustainability in their public communications, without having to consistently and persistently demonstrate that commitment in practice. Situated on this backdrop, the present review paper aims to concisely and selectively stitch together three streams of literature: (1) the rationale for sustainability and, by extension, sustainable energy consumption, in higher education; (2) the current state of sustainability planning and its (in)efficacy in institutions of higher education; and (3) effective practices for reducing energy consumption at scales comparable to university campuses.
\end{abstract}

Keywords: sustainability; energy efficiency; sustainability in higher education; university energy consumption

\section{Introduction}

As scientists continue to warm to the notion that the Earth is entering (or has already entered) an epoch characterized by human-induced changes to Earth surface conditions-i.e., the "Anthropocene"-more and more attention is being paid to the ecological consequences of uninterrupted population growth, its associated economic activities, and human consumption patterns in an ever-industrializing world [1]. Augmenting the ongoing descriptive and explanatory accounts of anthropogenic changes occurring in the environment [2-4], researchers are increasingly setting their sights toward action and affecting behavioral change [5]. In other words, there is a swell of interest in how humans, and, perhaps more importantly, human settlements, might function in more "sustainable" manners [6].

Given the prominent position of academia in the vast constellation of sustainability studies and sustainability science $[7,8]$, it is natural to want to look to universities-insofar as they often function as their own spatially-based communities [9] — as models of, or keepers of knowledge about, sustainability in practice [1]. Nevertheless, there is a long history of and literature on universities failing to implement their own sustainability initiatives—from student-initiated campaigns against the sale 
of bottled water [8] to a variety of projects aimed at increasing energy efficiency on campuses [10]. Apart from typical justifications for implementation failure that include budget constraints and financial infeasibility [8], one of the main obstacles that consistently keeps universities from achieving their sustainability-related goals is a lack of enforcement. More precisely, universities tend to codify their sustainability-related goals in non-binding declarations that are voluntary, and therefore non-mandatory [11]. In that respect, failure to achieve a goal does not result in any sort of formal sanction. As such, universities are free to claim a commitment to sustainability in their public communications, without having to consistently and persistently demonstrate that commitment in practice. Consequently, non-binding declarations are sometimes referred to as nothing but "greenwash" [11], as they do not produce organizational behavioral change or sustainable practice.

Situated on this backdrop, the present paper aims to concisely and selectively stitch together three streams of literature: (1) the rationale for sustainability and, by extension, sustainable energy consumption, in higher education; (2) the current state of sustainability planning and its (in)efficacy in institutions of higher education; and (3) effective practices for reducing energy consumption at scales comparable to university campuses. The focus on these three literature streams corresponds to the three themes and questions under investigation herein:

1. Why should universities serve as models for sustainable settlements, particularly with respect to energy consumption?

2. Why do universities tend to fall short of achieving sustainability-related goals, particularly with respect to energy consumption? And

3. How might universities begin to overcome constraints and commit more strongly to serving as models of sustainable settlements (with respect to energy consumption)?

\section{Why Should Universities Care about Sustainability and Sustainable Energy Use?}

The Stockholm Declaration of 1972 marked the first direct reference to "sustainability in higher education." Namely, in recognizing the inseparability of humanity and the environment, the Stockholm Declaration suggested several ways of achieving environmental "sustainability" [7], including but not limited to better education:

"A point has been reached in history when we must shape our actions throughout the world with a more prudent care for their environmental consequences. Through ignorance or indifference, we can do massive and irreversible harm to the earthly environment on which our life and well-being depend. Conversely, through fuller knowledge and wiser action, we can achieve for ourselves and our posterity a better life in an environment more in keeping with human needs and hopes" [12] (emphasis added).

Stated another way, in the aggregate, the ability of humans to live more sustainable lives in more sustainable settlements depends on the acquisition of knowledge. Accordingly, at the Stockholm Conference, education was highlighted as one of the most important leverage points for "fostering environmental protection and conservation" [13]. Approximately twenty years later, the Talloires Declaration, drafted in 1990 with more than 500 signatories from more than 40 countries, became the first official statement in which university administrators declared a commitment to environmental sustainability in higher education [14]. The non-binding ten points from that declaration concern education, research, involvement, and collaboration on environmental issues in higher education (Table 1). 
Table 1. Actions Enumerated in the Talloires Declaration (source: [14]).

\begin{tabular}{l} 
(1) Increase Awareness of \\
Environmentally Sustainable \\
Development \\
\hline (2) Create an Institutional Culture \\
of Sustainability
\end{tabular}

(3) Educate for Environmentally Responsible Citizenship

(4) Foster Environmental Literacy for All

(5) Practice Institutional Ecology

(6) Involve All Stakeholders

(7) Collaborate for Interdisciplinary Approaches

(8) Enhance Capacity of Primary and Secondary Schools

(9) Broaden Service and Outreach Nationally and Internationally

(10) Maintain the Movement
Use every opportunity to raise public, government, industry, foundation, and university awareness by openly addressing the urgent need to move toward an environmentally sustainable future.

Encourage all universities to engage in education, research, policy formation, and information exchange on population, environment, and development to move toward global sustainability.

Establish programs to produce expertise in environmental management, sustainable economic development, population, and related fields to ensure that all university graduates are environmentally literate and have the awareness and understanding to be ecologically responsible citizens.

Create programs to develop the capability of university faculty to teach environmental literacy to all undergraduate, graduate, and professional students.

Set an example of environmental responsibility by establishing institutional ecology policies and practices of resource conservation, recycling, waste reduction, and environmentally sound operations.

Encourage involvement of government, foundations, and industry in supporting interdisciplinary research, education, policy formation, and information exchange in environmentally sustainable development. Expand work with community and nongovernmental organizations to assist in finding solutions to environmental problems.

Convene university faculty and administrators with environmental practitioners to develop interdisciplinary approaches to curricula, research initiatives, operations, and outreach activities that support an environmentally sustainable future.

Establish partnerships with primary and secondary schools to help develop the capacity for interdisciplinary teaching about population, environment, and sustainable development.

Work with national and international organizations to promote a worldwide university effort toward a sustainable future.

Establish a Secretariat and a steering committee to continue this momentum, and to inform and support each other's efforts in carrying out this declaration.

The overarching objective of the Talloires declaration is to set in motion broad scale changes in universities rather than piecemeal planning and implementation [11]. In the same year as the Talloires Declaration, the U.S. Environmental Protection Agency (EPA) funded research at the Tufts University Environmental Center, known as Tufts CLEAN! (Cooperation, Learning, and Environmental Awareness Now!). The purpose of the grant was to study means for reducing the environmental impacts of the university's operations [15]. The Tufts team studied issues such as food waste, transportation, energy efficiency, and procurement practices to develop recommendations for several departments.

In another example, more than 680 universities signed the American College and University Presidents' Climate Commitment (AUPCC) agreement in 2006, which challenges participating institutions to reduce greenhouse gas emissions [16].

Among more recent attempts to introduce sustainable practices into American higher education, at the beginning of the 21st Century the U.S EPA explicitly proclaimed that "colleges and universities are required to comply with all applicable environmental requirements like their counterparts in the industry to create a safe haven for human health and environment" [17]. The Fundamental Change to Resource Conservation and Recovery Act (RCRA) regulation in higher education, proposed by the Campus Safety and Health Environmental Management Association (CSHEMA), suggests one possible policy 
for meeting the EPA's charge. Specifically, a regulatory reform and further guidance was proposed which would aid colleges and universities to meet their environmental commitment [18].

The current that underlies all the preceding examples is that "sustainability in higher education" is evidently a broader concept than simply incorporating "sustainability" into classroom curricula. More specifically, while there is a robust and valuable literature on "education for sustainability" (see, for example: [19-21]), institutions of higher education also have the power, and responsibility, to practice sustainability. Practice adds an observable and authentic dimension to the ways in which universities educate students and the public on important environmental issues. Indeed, universities can serve as models and test cases for programs and practices that could be scaled to the level of a whole human settlement, such as a neighborhood, multi-site corporation, or even a municipality. For, as Alshuwaikhat and Abubakar [7] (p. 1778) observe, universities are comparable to small cities in and of themselves. Similarly, Peter Viebahn observed that 334 different universities in Germany are comparable to large commercial institutions in terms of energy and materials consumption [22]. Creighton [15] believes that universities' and colleges' use of electricity, oil, natural gas, water, and chemicals might make their ecological footprints larger than any other entity in their home communities.

Along these lines, Agdas et al. suggest that "university campuses are [therefore] an excellent study set to assess the design and enforcement of sustainability and energy efficiency policies" [16] (p. 16). Furthermore, institutions like public universities, by virtue of their funding mechanisms, are expected to hold and display a commitment to the current and future well-being of their surrounding communities [23]. Thus, they tend to have a special social responsibility that commits them to sustainable practice [22].

In sum, then, a short answer to the question of why universities should care about sustainability and sustainable energy is threefold. First, as large educational and research-producing institutions, they are at the forefront of sustainability science and can therefore generate and disseminate important knowledge on sustainability science. Second, as small, semi-autonomous communities they have opportunities to implement evidence-based sustainable practices in order to demonstrate the efficacy of those practices to other types of human settlements. In this way, they can function as exemplars of sustainable communities to which planners and political decision-makers can look when developing their own sustainability initiatives. Finally, institutions of higher education have a special social responsibility to make their communities and the world around them better places in which to live.

\section{How Do Universities Express Commitment to Sustainability and Sustainable Energy Use?}

The issue of campus sustainability has been subject to intensifying scrutiny by governmental agencies and university stakeholders in light of the meaningful impacts that "the activities and operations of universities have on the environment" [7] (p. 1777). In response, many universities have authored and adopted sustainability vision statements and/or sustainability plans $[24,25]$. Such documents are means for communicating to the outside world that the given university takes sustainability seriously. Consider that during a recent Board of Regents meeting of the Texas State University System (TSUS), the TSUS chancellor observed that:

"Our administrators are not the only ones who will be aware of the environmental impact of water usage, temperature controls, insulation, and greener construction going forward. Our environmental performance will be increasingly scrutinized by the media, the public at large and our students. And, well it should! Therefore, I ask that each university president develop a detailed, campus-specific plan of action to improve environmental efficiencies" [26].

The benefits of a written plan or vision statement to a university's sustainability efforts are manifold. Above all, though, a clear vision statement and action plan are intended to communicate the "what" (e.g., how the university conceptualizes sustainability) and the "how" (i.e., the specific actions the university plans to take to be more sustainable, given the "what") of sustainability for an 
institution of higher education. Often, such plans provide information on a university's existing or proposed organizational structure and resources to achieve its sustainability vision [7].

As it turns out, though, while environmental issues are famously complex and multiscalar, most university sustainability plans provide only for simple strategies and small-scale solutions [7]. This is so in spite of the fact that common definitions of sustainable universities and sustainable campuses tend to embrace the multidimensionality of the "sustainability" concept. For example, Velazquez et al. [27] state that an institution of higher education, "as a whole or as a part, that addresses, involves and promotes, on a regional or a global level, the minimization of negative environmental, economic, societal, and health effects generated in the use of their resources in order to fulfill its functions of teaching, research, outreach and partnership, and stewardship ... help society make the transition to sustainable lifestyles" [27] (p. 812).

Relatedly, Alshuwaikhat and Abubakar [7] define a sustainable campus specifically as one that balances well-known tensions between economic prosperity, ecological and environmental conservation, and social and economic justice. To the extent that a university can find ways to promote ecological stewardship in cost effective ways that provide benefits across socioeconomic and demographic spectrums, they have opportunities to export sustainability values and sustainability practices to communities, on national and global levels [7].

In these two representative uses of the term "sustainability" with respect to institutions of higher education, it is clear that sustainability for colleges and universities goes beyond environmental concerns to address social and, particularly, economic challenges as well (i.e., the "Three Es" of economic development, environmental/ecological stewardship, and equity). Crucially, while the concept of sustainability is indeed subject to many different and conflicting interpretations [28], and has no standard operational definition to facilitate measurement [27], perhaps the most common image of the idea-that "the need of present should not compromise the ability of future generation to meet their own needs" [29] — is said to provide "a convenient point of departure for a broad understanding of this fairly abstract concept" [30] (p. 4). With that in mind, it is important to note that economic growth has, historically, been a key part of this "broad understanding" [30] (p. 4)—whereby growth remained (remains) the key goal of society, so long as it did (does) not interfere with the opportunities available to future generations [28].

Daly and Cobb [31] were among the earliest influential scholars to question this prioritization and speculate that it is infeasible to achieve sustainability in a world of significant positive economic growth [32]. There are now large and influential lines of scholarship that suggest moving toward sustainability will require limits to economic growth and increasing attention to other complex social issues such as inequality, poverty, racism, and access to health care (e.g., [33]). However, college and university plans related to sustainability, by and large, seem to convey their institutions' desires to continue to grow and expand, but in ways that are "greener" and less harmful to the environment. In that sense, they may be little more than "greenwash" [11]. The following subsection engages with sustainability plans and planning in higher education, with a particular emphasis on energy use.

\section{Sustainability Plans in Higher Education: Emphasis on Energy Use}

As of 2011, there were more than 30 sustainability programs in higher education signed by over 1400 universities worldwide [34]. While many universities experience difficulties in implementing these programs, Clarke and Kouri [35] state that the overarching commitments-in the form of declarations-lay the foundations for individual, tailored sustainability policies at universities [34].

That being said, according to the Association for the Advancement of Sustainability in Higher Education (AASHE), best operational practices in energy efficiency are relatively consistent across universities [16]. These practices include temperature set-points for Heating, Ventilation, and Air Conditioning (HVAC) systems, multiple/individual zones for controls, and assigning individual responsibilities for saving energy, among other measures. Leadership in Energy and Environmental Design (LEED) as a rating system certification appears to be the most prominent 
design-related guideline in campus sustainability declarations; however, according to Agdas et al. [16] "the certification guidelines are not necessarily devised to serve this purpose" [16] (p. 16).

As an emerging university, Universitas Indonesia (UI), developed a web-based green ranking tool for world universities based on several environmental indicators [36]. The UI ranking program is an early prototype of an anticipated global tool for assessing universities' sustainable behavior [34]. The UI GreenMetrics Ranking, launched in 2010, is designed to be suitable for universities in both developed and developing countries; however, researchers have cautioned that some important indicators and criteria require significant revisions or improvements [36]. Despite these limitations, though, the UI GreenMetrics Ranking serviceably computes carbon footprints to rank universities, providing decision-makers with empirical data that can be used in internal or external assessments of an institution's progress with respect to reducing its environmental impacts-both in absolute terms and relative to other institutions. In 2013, 301 universities from 61 countries participated in the study, a 40 percent increase form 2012. The three highest ranked universities identified during that study are listed in Table 2.

Table 2. The 2013 ranking of UI GreenMetrics with the best 3 ranked universities.

\begin{tabular}{lc}
\hline \multicolumn{1}{c}{ University } & Score \\
\hline University of Nottingham (UK) & 7521 \\
University College Cork National University of Ireland & 7328 \\
Northeastern University (USA) & 7170 \\
\hline
\end{tabular}

While measurement offers universities the ability to monitor progress in terms of environmental impacts, strategies and actions for reducing those impacts are what is needed to achieve progress. In that regard, three sustainability approaches relevant to university practices have been highlighted by Alshuwaikhat and Abubakar [7]: (1) Green building initiative; (2) ISO 14001, a standard developed in 1996 and updated in 2004 and 2015, which enables organizations to develop policy and objectives considering legislative requirements and information about significant environmental impacts; and (3) European Eco-Management and Audit Scheme (EMAS). The green building initiative aims to create enabling conditions for a series of projects to reduce the production of waste and hazardous materials, reduce level of energy consumption and promotes the energy efficient design [7]. The ISO 14001 standard applies a regular auditing alongside implementation of environmental goals, policies, and responsibilities [7]. EMAS, developed in 1993, is more demanding, more difficult to implement, and must correspond to environmental declarations, which has been highlighted as a weakness [7,37]. Because it is the base of the Osnabruck model, which is discussed below, it will not be further unpacked at this stage.

In addition to the aforementioned techniques, several programs exist to promote energy efficiency on campus and beyond. The most famous, Energy Star, is a product of the U.S. EPA. Leadership in Energy \& Environmental Design (LEED) is the most famous certification for energy savings at the building scale. Indeed, according to Agdas et al. [16], the LEED system "is the most widely accepted and adopted Building Rating System (BRS) in the U.S. with a total of over 44,000 registered and certified buildings since 2001" (p. 16). However, research has shown that the mean Electricity Utilization Index (EUI) of existing LEED buildings might actually be larger (331.20 kBtu/sf/yr) than non-LEED buildings (222.70 kBtu/sf/yr) - though median EUIs for the two classes of buildings appear to be more similar $\left(\mathrm{EUI}_{\mathrm{LEED}}=172.64\right.$ and $\left.\mathrm{EUI}_{\text {non-LEED }}=178.16\right)[16](\mathrm{p} .16)$.

The Energy Management System (EMS), another sustainable energy use framework, shares some intellectual ground with ISO 14001. Specifically, as noted by Savely et al. [18], EMS features a list known as "16 Environmental Elements" - effectively a check list for universities interested in moving toward more sustainable energy use. The 16 elements are:

- An environmental policy,

- An accounting of university activities that may affect the environment, 
- Environmental programs with objectives and targets,

- An accounting of legal requirements applicable to environmental issues,

- An organizational chart that connects specific environmental matters to specific individuals,

- Routine reporting requirements for administrative monitoring purposes,

- Training and education programs for employees,

- Documentation of all internal and external communications about environmental matters,

- A system to ensure that personnel are working with the most current version of environmental procedures,

- Functional environmental emergency preparedness and response procedures,

- A set of measurable indicators for all operations that have environmental impacts,

- Sanctioning procedures to correct non-compliance with environmental practices,

- Protocol for managing and storing environmental records,

- A system for routine internal audits of environmental programs,

- A system for routine third party audits of environmental programs, and

- Periodic environmental program reviews by upper institutional management [18].

The Osnabruck environmental management model for universities is based on the EMAS Directive of the European Union. This model corresponds in many ways (except for six points) to the ISO 14001 standards [18]. The Osnabruck model was created on ten different blocks of buildings and measures and provided the University of Osnabruck with a scheme to follow for the final introduction and continuation of an environmental model applicable to all universities [22]. Relatedly, an important study by Dixon and McMordie [38] was prepared for the U.S. Department of Energy (DOE) in order to facilitate energy-efficiency improvements at federal facilities. Dixon and McMordie reviewed eight different assessment methods for energy efficiency in buildings comparing their scope, strength, and limitation. The methods reviewed by Dixon and McMordie are the following, and readers are encouraged to see Ref. [38] for additional information on these methods:

- Renewables and Energy Efficiency Planning (REEP)

- $\quad$ Facility Energy Decision Screening (FEDS)-Level 1

- $\quad$ Facility Energy Decision Screening (FEDS)-Level 2

- Systems Engineering and Management Corporation (Systems Corp.) Manual Audit

- XenCAPTM

- $\quad$ Federal Lighting Energy Expert (FLEX)

- $\quad$ Lighting Technology Screening Matrix (LTSM)

- Green Lights Program.

To improve the energy efficiency in the university environment, some recommended renovation-related activities include lighting system upgrades, window film installation to minimize the absorption of heat, occupancy sensors to turning on/off the lighting system or other automated systems, optimization of parking garage, office equipment power management, and improving occupant behavior [39]. However, upon listing these recommendations, Kozman et al. [39] limit their study to consider only solutions that have a rapid simple payback period (SPP) of about one year or less, where SPP is:

$$
\mathrm{SPP}=\text { cost to make the change/energy cost savings per year }
$$

However, the downside of reducing sustainability decisions exclusively to financial-economic matters is that it overlooks more ethical and moral dimensions of the decision calculus (the other "Es" of social equity and ecological stewardship). For instance, because universities make a significant contribution to knowledge development in society, they ought to have a special social responsibility when it comes to the sustainable protection of the environment and the use of resources [22]. That is 
why even a gradual change in universities might not be considered as an appropriate response-relative to more transformational changes—given their positions of prominence in society [11].

A handful of studies have gone beyond building design and energy consumption to consider the material used in constructing a building (e.g., [23]), where embodied energy becomes a factor which shows the energy consumed by all the processes associated with the production of a building, from the mining and processing of natural resources to manufacturing, transport, and product delivery [40]. Per Suwartha \& Sari [36], only a few institutions have measured their effort and rated the university's performance in these terms. Green League 2007 is one example, wherein the environmental performance of Britain's universities was evaluated on percentage of energy purchased from renewable sources, percentage of waste recycled, and $\mathrm{CO}_{2}$ emissions for each institution [36]. Another example is given by the Environmental and Social Responsibility (ESR) index [36].

\section{How Might Universities Better Commit to Sustainability? Building Energy Performance as a Leverage Point}

Given the (1) justifications for why higher education institutions ought to be leaders in sustainability practice (Section 2) and (2) history of links between university sustainability plans/programs, building (re)design and renovations, and energy use (Section 3), building energy performance is arguably a key leverage point where relatively immediate interventions can help universities consume energy more "sustainably" in practice. Indeed, administrators budget annually for maintenance, operation, and renovation costs, as well as energy costs. Accordingly, decision-making in these domains happens regularly and often, which means that universities have recurring opportunities to move away from "business as usual" and toward more sustainable energy consumption futures. For these reasons, the remainder of this article zeros in on building energy performance as an initial action space wherein university officials can begin making decisions that demonstrate institutional commitments to sustainable energy use.

To begin, note that the environmental impacts of buildings are staggering. Consider that in Europe, buildings account for $40 \%$ of total energy use and $36 \%$ of total $\mathrm{CO}_{2}$ emissions [41]. Globally, buildings were estimated to be responsible for $35 \%$ to $45 \%$ of the global annual energy consumption in 2010 [42]. Along these lines, buildings are spaces where energy savings innovations have the potential to make substantial, positive environmental impacts. To realize these possibilities, it is imperative to understand how buildings consume energy. On that matter, Zhao and Magoulès [41] have identified numerous factors related to building energy performance, including weather and climatic conditions (especially dry-bulb temperature), thermal properties of physical construction materials, building use and user behaviors, sub-level components such as lighting and HVAC systems, and the performance and schedules of these systems [41].

Among higher education institutions that have expressed interest in enhancing building energy performance, the idea of a "green building" has varied across universities and across regions based on factors like climate and primary use. Commonly, though, green buildings are those that include mechanisms for decreasing waste and hazardous material, while demanding fewer energy resources [7]. Moreover, the green building concept generally calls for the use of local materials to avoid the transportation costs and pollution [7]. While "local materials" and important factors like climate vary from place to place, LEED and other Building Rating Systems (BRSs), which are intended to promote energy efficiency, offer relatively standard ways to evaluate the performance of green buildings [16].

Prior to moving onto the key parameters that these and related systems consider important to sustainability in building energy performance, it is useful to quickly consider current conditions of higher education buildings. The State of Facilities in Higher Education report, published in 2014 by Sightlines, documents major trends regarding the construction of new space in higher education system, termed waves of construction. In the United States, for example, one can point to three waves of construction. In order of importance: (1) during the 1960-1970s building boom, almost $40 \%$ of current university spaces were constructed. In this era, demand for universities was high, and rapid 
construction was facilitated by installation of low quality mechanical systems that manage building environmental conditions. Consequently, many of these spaces, even when they are renovated, often fail to meet today's needs and environmental standards [43]; (2) The second most important wave includes buildings constructed after 1995, now known as Millennial Expansion, when 30\% of all buildings constructed; Finally, (3) the pre-war era was the first wave in chronological order, during which the remaining $30 \%$ of all current university spaces were constructed.

\subsection{Sustainability Parameters in Buildings}

There are several parameters or sustainability criteria used to calculate the environmental impact of a facility, such as greenhouse gas emissions, energy consumption, resource depletion, land degradation, and financial implications [23]. Of primary importance to this article, Viebahn has stated that environmental pollution occurs in all parts of university facilities from laboratories to administration offices. A significant reduction of pollution can be achieved by a "systematic implementation of organizational and technical measures" [22].

Growing world energy use creates issues related to supply shortages, unstable prices, and heavy environmental impacts, especially in terms of climate change [44]. Data on energy consumption trends produced by the International Energy Agency show that during the two decades from 1984-2004, primary energy usage grew by $49 \%$ and $\mathrm{CO}_{2}$ emissions by $43 \%$, with an average annual increase of $2 \%$ and $1.8 \%$ respectively [45]. In an update to that study, the International Energy Agency predicted there will be a 30\% increase in energy demand in the next years, mostly from developing countries [45]. Similarly, according to the 2016 World Energy Outlook, there will be a 50\% growth in demand for natural gas, suggesting it will soon overtake coal in the global energy market.

According to Ref. [46], the implications of these changes are dire. Climate change is already making places hotter, and "much greater temperature increases are expected in the coming decades. Along with increasing temperatures, precipitation patterns are shifting, extreme weather events such as storms and droughts are increasing, and sea levels are rising" [46] (p. 3).

Perhaps the most basic, but important, implication of climate change for building managers is this: hotter summers and colder winters mean higher energy demand, especially with increased peak electricity consumption for air conditioning. Even the water supply can be affected by weather conditions, given its important role in cooling systems [46]. Richard Tol has argued that "one cannot have cheap energy without carbon dioxide emission" [47] (p. 29). According to the U.S. Energy Information Administration (EIA), in 2015 about $67 \%$ of electricity generated nationally was from fossil fuels such as coal, natural gas, and petroleum. In the same year, emissions of carbon dioxide $\left(\mathrm{CO}_{2}\right)$ by the U.S. electric power sector were 1925 million metric tons, or about $37 \%$ of the total U.S. energy-related $\mathrm{CO}_{2}$ emissions (5271 million metric tons) [48]. Table 3 shows updated data for 2016. Globally, carbon dioxide emissions have increased by almost $50 \%$ since 1990, and emissions grew more quickly between 2000 and 2010 than in any of the three previous decades [49].

The sources of greenhouse gas emissions can be found everywhere, from homes to big industrial companies. The American electric-power sector is the largest source of GHG emissions in the United States economy [50]. The former President of the United States, in his recent article in Science, stated that the total energy consumption in 2015 was $2.5 \%$ lower than it was in 2008, even as the economy was $10 \%$ larger [50]. According to Enerdata, the amount of reduction reaches $3.5 \%$ comparing the same range of time reflected in Figure 1. The total energy consumption in the United States dropped from 2278 Mtoe (Million tonnes of oil equivalent) to 2196 Mtoe [48]. This amount of reduction in energy consumption would have a significant drop in pollutants production. This information suggests that the government of the United States has been seriously committed to reducing GHG emissions as it continues to pursue economic growth. In the past eight years, for instance, " $\mathrm{CO}_{2}$ emissions from the energy sector fell by $9.5 \%$ from 2008 to 2015 , while the economy grew by more than $10 \%$ " [50] (p. 1). Nevertheless, the new administration in the U.S. so far does not seem to take climate change seriously [51]. Moreover, climate change does not respect national borders, meaning that any of the U.S.'s past actions, or actions 
of any one nation on its own, are not sufficient to reduce the rapid environmental degradation. To overcome this drawback, the Paris Agreement, with more than 110 cosigner countries, representing more than $75 \%$ of global emissions, is a serious promise to reduce emissions globally [50]. However, per the International Energy Agency, even if nations are abiding by Paris Agreement (NB: the Paris Agreement on climate change, which entered into force in November 2016, is aimed at reducing energy consumption) pledges, energy sector $\mathrm{CO}_{2}$ emissions are not on track for a $2^{\circ} \mathrm{C}$ reduction. Such a reduction is the target scenario, and to achieve this goal the energy sector "must be carbon-neutral by $2100^{\prime \prime}$ [45]. The path to keep the temperature raise under the $2^{\circ} \mathrm{C}$ guideline is achievable only if policies aim to accelerate further low carbon technologies and energy efficiency standards are applied in all sectors.

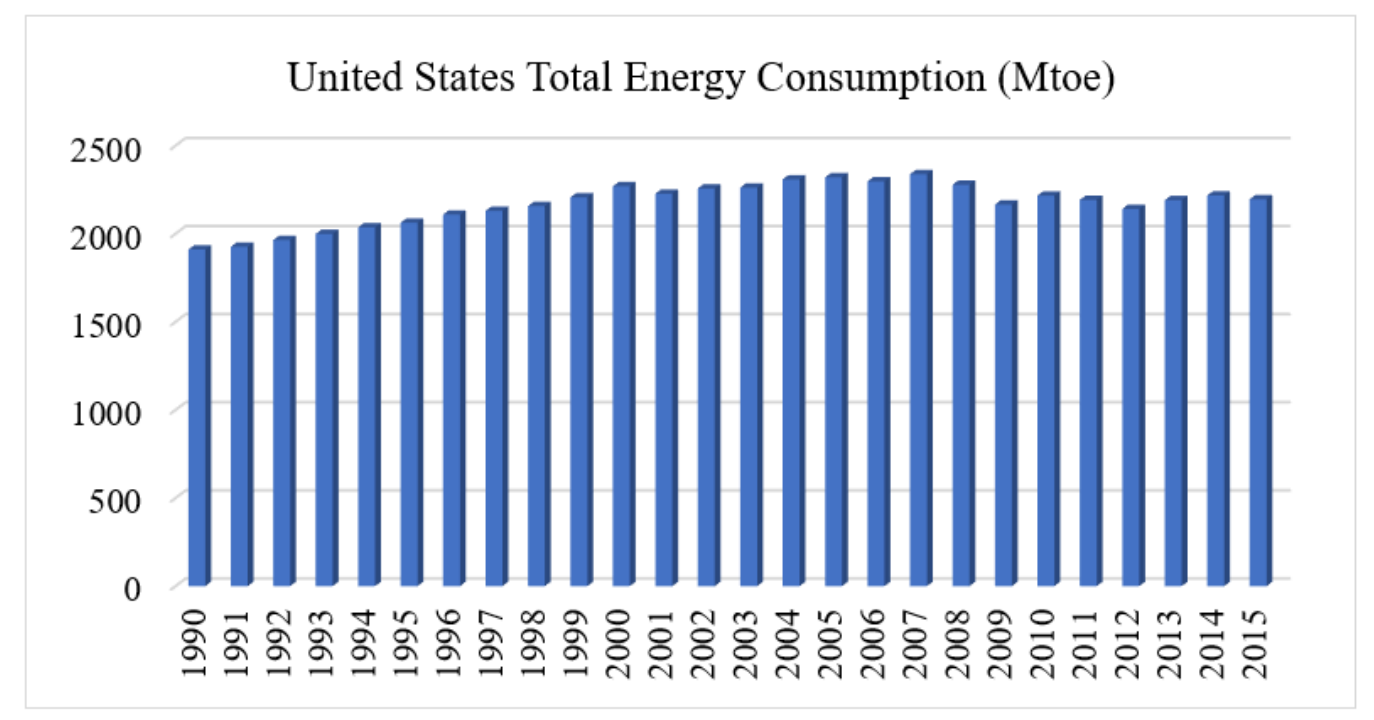

Figure 1. United States total energy consumption (Mtoe), Data Source: Enerdata.

Table 3. $\mathrm{CO}_{2}$ emissions from U.S. electric power sector by source, 2016. Source: EIA.

\begin{tabular}{ccc}
\hline Source & Million Metric Tons & Share of Total \\
\hline Coal & 1241 & $68 \%$ \\
Natural gas & 546 & $30 \%$ \\
Petroleum & 21 & $1 \%$ \\
Other & 12 & $<1 \%$ \\
Total & 1820 & $100 \%$ \\
\hline
\end{tabular}

While these realities are troubling, according to the World Energy Outlook from 2015, there is reason to believe that lower carbon energy options might meaningfully compete with their high emissions counterparts in the near future. In particular, "as oil and gas gradually become more expensive to extract [and] the costs of renewables ... continue to fall," policy and consumer preferences will plausibly be steered toward the latter [45].

With that in mind, note that it might also be possible to reduce fossil fuel consumption, and move toward the target reduction scenario, by reducing electricity usage. According to the United Nations Sustainable Development Goals, a sustainable and modern energy should be affordable for all and can act as a leverage point from which to transform lives, economies, and the planet as a whole. The surge of interest in energy efficiency measures recently pushed stakeholders in the southern United States to ask how much wasted energy can be avoided by expanding investments in cost-effective technologies and practices [52]. In the resultant study—which focused on residential and commercial buildings and industry (RCI), but is relevant to higher education due to the fact that University campuses function 
like small cities that contain plants for distributing energy and buildings with energy consumption levels comparable to commercial buildings [7]—Brown et al. found the following:

1. Aggressive energy-efficiency initiatives in the southern U.S. could prevent energy consumption in the RCI sectors from growing over the next twenty years. In absence of such initiatives, energy consumption in these three sectors is projected to grow by approximately $16 \%$ between 2010 and 2030.

2. Fewer new power plants would be needed with a commitment to energy efficiency. Nine policies (see [52] p. 21), (Table 4), can help offset the need to construct 49 GW of new plants to meet a growing electricity demand from the RCI sectors.

3. Increased investments in cost-effective energy efficiency would generate jobs and cut utility bills. The cost/benefit ratios for the modeled policies range from 4.6 to 0.3 , with only two recommended policies showing costs greater than benefits. When the value of saved $\mathrm{CO}_{2}$ is included, only one of Brown et al.'s nine recommended policies is not cost effective (Table 4).

4. Energy efficiency would result in significant water savings since water is the main material used in cooling systems.

Table 4. Nine energy-efficiency policies (Adapted from [52]).

\begin{tabular}{ccc}
\hline Residential Buildings & Commercial Buildings & Industry \\
\hline $\begin{array}{c}\text { Appliance Incentives } \\
\text { and Standards * }\end{array}$ & $\begin{array}{c}\text { Aggressive Commercial } \\
\text { Appliance Standards }\end{array}$ & Process Improvement Policy \\
\hline $\begin{array}{c}\text { Residential Retrofit and } \\
\text { Equipment Standards }\end{array}$ & Commercial Retrofit Incentives & $\begin{array}{c}\text { Assessments of Plant } \\
\text { Utility Upgrades }\end{array}$ \\
\hline $\begin{array}{c}\text { Expanded Weatherization } \\
\text { Assistance Program }\end{array}$ & & $\begin{array}{c}\text { Combined Heat and } \\
\text { Power Incentives * }\end{array}$ \\
\hline Building Codes with & & \\
Third-Party Verification & & \\
\hline
\end{tabular}

There was also an emphasis on energy consumption as one of the principal parameters for assessing environmental performance of a facility highlighted by activities of the Australian Greenhouse Office, the Australian Building Energy Council, the Australian Building Codes Board and the proposal to incorporate minimum energy efficiency requirements in the building codes [23].

According to Sightlines' The State of Sustainability in Higher Education report in 2015, a significant number of universities mobilized to offer leadership in climate change contributing to Carbon Commitment featuring the carbon management hierarchy to tackle best practices in reducing greenhouse gases emissions. The Intergovernmental Panel on Climate Change (IPCC), in its 2014 report, emphasized the role of reduction in building energy use which lowers greenhouse gas emissions and reduces global warming trends. The first point in the Summary for Policymakers included in the final report of Ref. [53] states that:

Human influence on the climate system is clear, and recent anthropogenic emissions of greenhouse gases are the highest in history. Recent climate changes have had widespread impacts on human and natural system.

Based on previous paragraphs, it is essential to apply a significant energy reduction in campuses to enhance the environmental commitment of universities. It is also known that improving energy efficiency is the key to reducing GHG emissions [54]. One of the ways to attain the more-efficient use of energy in an industry is to determine the amount of energy used and energy losses [54].

\subsection{Enrollment, Space, and Energy}

There are several facts highlighted by the Sightlines report in 2015 regarding the relationship between space and enrollment. Texas and Utah are the two states with a continuous increase in 
high school enrollment caused by migration and immigration. Public campuses in Texas are often overcrowded. The enrollment has increased by $8 \%$ between 2007 and 2011 and "since 2011 enrollment has flattened out and by 2013 and 2014 the rate of growth was in decline". However, the average of space for each student or member has continued to grow; since 2007 campuses have increased the average space by $10 \%$, but now only have $7 \%$ more students [43].

As an example, Texas State University in the past 19 years has recorded a steady growth in the numbers of students and enrollment. According to the Texas State University Office of Institutional Research, the quantity of enrollments for the fall semester increased from 27,485 in 2006 to 38,808 in 2016. Registering a gradual growth in the university enrollment does not necessarily mean a higher level of energy consumption. But, continued and significant growth together with infrastructure modifications and new constructions with a $5.7 \%$ net increase in gross square feet during the past four years demand an extensive energy conservation and information plan to achieve the energy saving opportunity.

Due to the dramatic global environmental state, many universities around the world have decided to subscribe to different sustainable development plans regardless to the number of their members. The University of Osnabruck with 14,000 members in 2002 is an example of environmental commitment by assuming a special social responsibility providing a road map to the future decision makers [22].

Sightlines provides another useful fact by looking at the amount of space per student over time. Public and private universities have gradually added more space per student from 2007 to 2014. Public campuses have 350 gross square feet/student; private campuses have 600 gross square feet per student. However, "the bottom line is that campuses are getting less dense; overall, they have more space for their students than ever before". Figure 2 shows the space growth and enrollment average between 2007 and 2014.

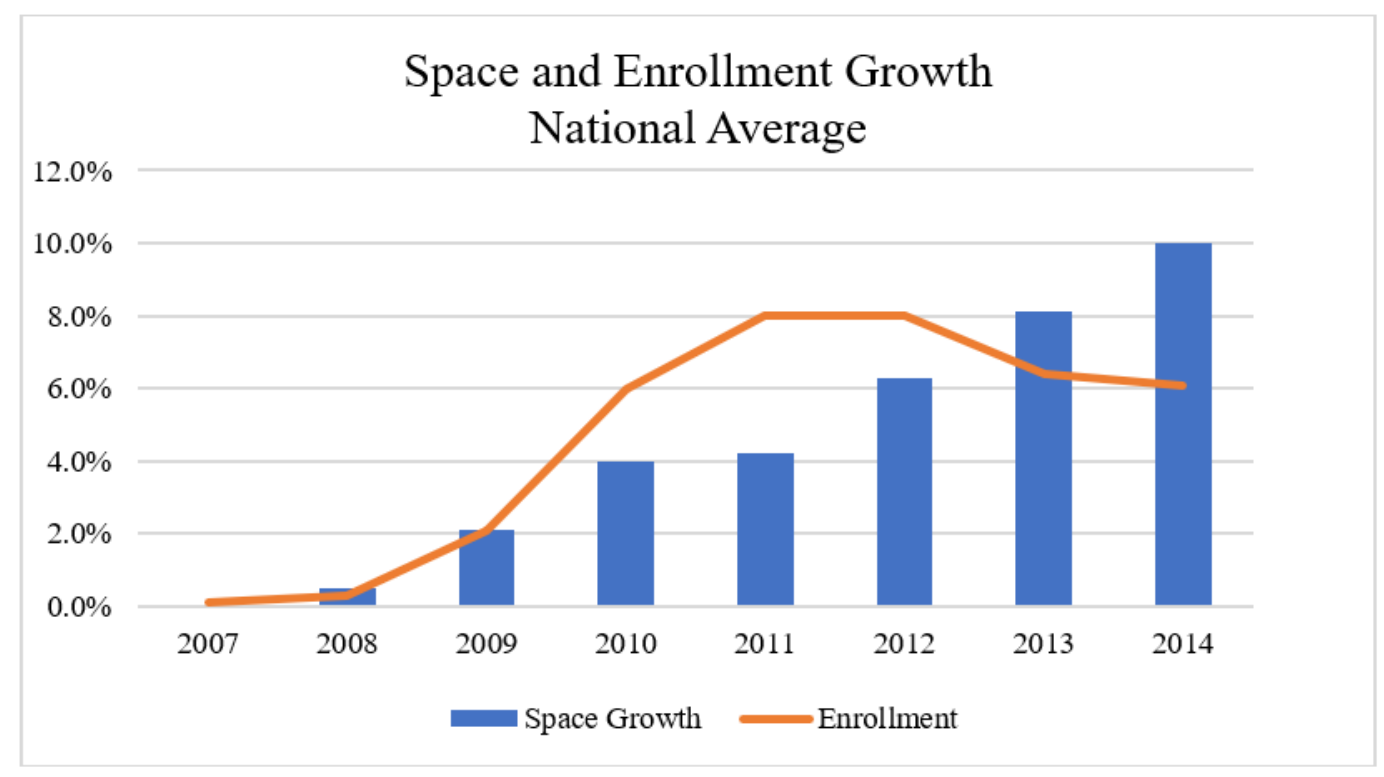

Figure 2. Space and enrollment growth national average. Source: Sightlines State of Facilities in Higher Education report, 2015.

Studies have shown that many institutions are re-evaluating the space dedicated to their campuses through financial analysis with especial attention towards energy efficiency measures and cost savings [43]. One example is the University of Maine System. In a 3 January 2014 report, the system noted that "the current multi-year financial analysis indicates the ... System has more space than it can afford to sustain, and ... the facility portfolio continues to age and grow more costly". Because of this evaluation, the university has adopted policies to reduce the total square footage of their campuses [43]. 


\section{Beyond Social Responsibility: More Sustainable Energy Consumption Can Save Universities Money}

Large institutions like universities, as well as most businesses, agree that reducing emissions in addition to the significant improvement of environment "can boost bottom lines, cut costs for consumers, and deliver returns for shareholders" [50]. Following these details, the Obama Presidential administration introduced energy efficiency standards that are projected to cut more than 10.4 billion tons of carbon pollution over the next 15 years in the United States [50].

This policy development aligns with the concept of rational use of energy which aims at reducing energy use and corresponds to the optimum use of all limited economic resources [54]. The consumption of energy covers a great portion of budget spending in university environment. Consider again the case of Texas State University, where a huge portion of cost is driven from electricity. The University's CoGeneration Power and Chiller Plant, which is in charge with providing energy for more than 80 facilities consumed 62,269,842 kWh (212,527 MMBtu) (Million British Thermal Unit) of electricity in the billing period between April 2015 and April 2016, which covers more than 75\% of the University's total cost for energy (Figure 3). In financial terms, this means $\$ 5,146,463.39$ with an average cost of $\$ 0.0826 / \mathrm{kWh}$. This is while electricity covers only $36.5 \%$ of use percentage and natural gas consumption constitutes $63.5 \%$ of total use percentage with an average price of $\$ 4.3749 / \mathrm{MCF}$ (Thousand Cubic feet of Natural Gas) (Figure 4).

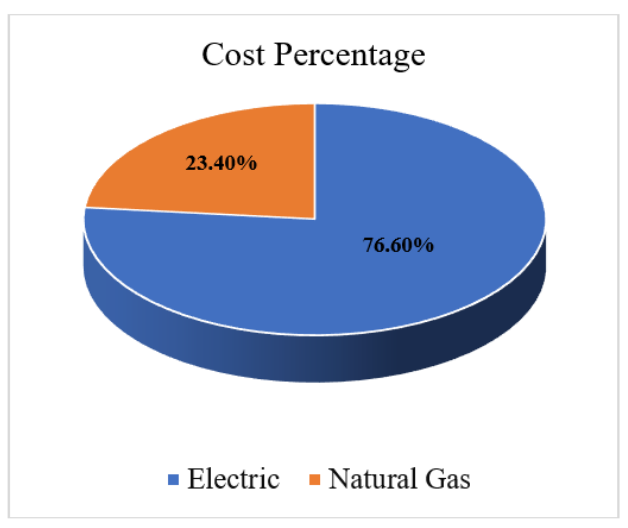

Figure 3. Cost percentage of energy at Central Plant (CoGeneration Plant).

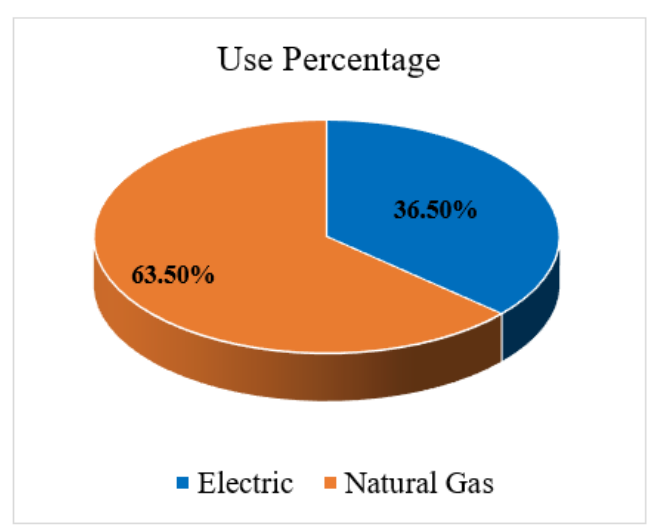

Figure 4. Use percentage of energy at Central Plant (CoGeneration Plant).

The predominance of electricity consumption (and cost) is verifiable in other universities besides the proportion, year of construction, and other factors. The city West campus of the University of South Australia on North Terrace, Adelaide is another example provided by the study of Pullen [23] where eight buildings over four levels with a floor area of approximately $30,000 \mathrm{~m}^{2}$ rely on electricity 
with a very small amount of reticulated gas as their primary source of energy. The annual averages were converted to primary energy by means of factors of 1.22 for gas and 3.12 for electricity [23].

Many universities are spending more than needed on energy. According to Kozman et al. [39], this fact was observed at the University of Louisiana at Lafayette where cutting back on energy usage was a practical way of saving money. Per Viebahn [23], if the University of Osnabruck were to reduce its energy consumption by just 20\% it could save 500,000 Demand Management (DM) in energy costs every year.

The U.S. Energy Information Administration (EIA) states that in 2015 about $67 \%$ of the electricity generated was from fossil fuels such as coal, natural gas, and petroleum. All these types of fuels are directly correlated to the greenhouse gas emissions. The World Energy Outlook in 2015 states that the price of oil and gas production are increasing since operators must move to smaller, more remote or more challenging reservoirs. World Energy Outlook [55] states that:

By contrast, cost reductions are the norm for more efficient equipment and appliances, as well as for wind power and solar PV, where technology gains are proceeding apace and there are plentiful suitable sites for their deployment [55].

It is recognizable that energy efficiency projects can save money but as stated by the former President of the United States "it also has the potential to create jobs that pay well" [50]. Approximately 2.2 million Americans are employed in design, installation, and manufacture of energy-efficiency products and services compared to 1.1 million Americans employed in the production of fossil fuels used to produce electric power [50].

\section{Conclusions and Directions for Future Research}

The literature on sustainability and energy use in higher education largely agree that environmental protection is the responsibility of all university stakeholders, as members of society. These responsibilities are incumbent on us whether at work on campus, or in the classroom, and when travelling to and from the university [22]. In that sense, universities are challenged to function as models of sustainable communities. Situated on this argument, the foregoing review paper attempted to summarize, in broad strokes, how universities currently plan for and move toward sustainability—as well as how campuses might better commit to sustainability—particularly with respect to energy use. In general, it seems that the use of non-binding sustainability plans is common in institutions of higher education, which often results in implementation failure (e.g., [11]). Given that numerous sustainable energy use frameworks exist, and, importantly, have proven to be cost effective [52], perhaps substantive overhauls to university energy practices and building standards can act as important first steps in reorienting campuses toward more sustainable futures.

That being said, to the extent that this article attempted to synthesize three large bodies of literature, the review was necessarily non-exhaustive. If we are committed to pushing the sustainability agenda forward in institutions of higher education, then an important next step is to highlight and discuss universities (and their campus plans and practices) that are progressing toward more sustainable futures. A review of such cases, with an eye toward best practices, would be an important follow-up to this research.

At the same time, while the preceding literature review documented some well-studied barriers to implementing sustainability initiatives on university campuses-particularly financial constraints [8] and the use of non-binding declarations that lack enforcement mechanisms [11] —it did not grapple with existing and emerging political barriers to sustainability. In particular, within just the past three years, directives from official state [56] and federal [51] government agencies in the United States advised staff members to discontinue using the term "climate change" in official reports and communications. In states where climate change skepticism sentiments exist at the highest levels of government, public universities in particular, which tend to receive significant amounts of funding from state governments, might feel pressure to back away from both the language of sustainability and any initiatives intended to mitigate environmental impacts. Given the recency of these directives 
and related political discourse, new research into political barriers will be a timely and valuable contribution to this line of research.

Author Contributions: Conceptualization, M.M. and R.W.; Validation; M.M. and R.W.; Writing-Original Draft Preparation, M.M.; Writing-Review \& Editing, R.W.

Funding: This research received no external funding.

Conflicts of Interest: The authors declare no conflict of interest.

\section{References}

1. Ralph, M.; Stubbs, W. Integrating environmental sustainability into universities. High. Educ. 2014, 67, 71-90. [CrossRef]

2. Sagan, C.; Toon, O.B.; Pollack, J.B. Anthropogenic albedo changes and the earth's climate. Science 1979, 206, 1363-1368. [CrossRef] [PubMed]

3. Barnett, T.P.; Pierce, D.W.; Schnur, R. Detection of anthropogenic climate change in the world's oceans. Science 2001, 292, 270-274. [CrossRef] [PubMed]

4. Rosenzweig, C.; Karoly, D.; Vicarelli, M.; Neofotis, P.; Wu, Q.; Casassa, G.; Tryjanowski, P. Attributing physical and biological impacts to anthropogenic climate change. Nature 2008, 453, 353. [CrossRef] [PubMed]

5. McKenzie-Mohr, D. Fostering Sustainable Behavior: An Introduction to Community-Based Social Marketing, 3rd ed.; New Society Publishers: Gabriola Island, BC, Canada, 2011; ISBN 978-1-55092-462-6.

6. Mazmanian, D.A.; Kraft, M.E. Toward Sustainable Communities: Transition and Transformations in Environmental Policy, 2nd ed.; MIT Press: London, UK, 2011; ISBN 978-0-262-13492-7.

7. Alshuwaikhat, H.M.; Abubakar, I. An integrated approach to achieving campus sustainability: Assessment of the current campus environmental management practices. J. Clean. Prod. 2008, 16, 1777-1785. [CrossRef]

8. Elliott, H.; Wright, T. Barriers to Sustainable Universities and Ways forward: A Canadian Students' Perspective. Paper Presented at the 3rd World Sustainability Forum. 2013. Available online: https: //www.researchgate.net/profile/Heather_Elliott2/publication/269203082_Barriers_to_Sustainable_ Universities_and_Ways_Forward_A_Canadian_students_Perspective/links/572a469f08ae2efbfdbc1d24 / Barriers-to-Sustainable-Universities-and-Ways-Forward-A-Canadian-students-Perspective.pdf (accessed on 5 October 2016).

9. Norton, R.K.; Brix, A.; Brydon, T.; Davidian, E.; Dinse, K.; Vidyarthi, S. Transforming the University Campus into a Sustainable Community. Plan High. Educ. 2007, 35, 22-39.

10. Maiorano, J.; Savan, B. Barriers to energy efficiency and the uptake of green revolving funds in Canadian universities. Int. J. Sustain. High. Educ. 2015, 16, 200-216. [CrossRef]

11. Bekessy, S.; Samson, K.; Clarkson, R. The failure of non-binding declarations to achieve university sustainability: A need for accountability. Int. J. Sustain. High. Educ. 2007, 8, 301-316. [CrossRef]

12. Declaration Stockholm. Declaration of the United Nations Conference on the Human Environment. 1972. Available online: http:/ / www.unep.Org/Documents.Multilingual/Default.Asp (accessed on 4 August 2016).

13. Lozano, R.; Ceulemans, K.; Alonso-Almeida, M.; Huisingh, D.; Lozano, F.J; Waas, T.; Hugé, J. A review of commitment and implementation of sustainable development in higher education: Results from a worldwide survey. J. Clean. Prod. 2015, 108, 1-18. [CrossRef]

14. Talloires Declaration. University Leaders for a Sustainable Future. 1990. Available online: https://ulsf.org/ about/ (accessed on 8 december 2018).

15. Creighton, S.H. Greening the Ivory Tower: Improving the Environmental Track Record of Universities, Colleges, and Other Institutions, 1st ed.; The MIT Press: Cambridge, MA, USA; London, UK, 1998; ISBN 0-262-53151-8. Available online: http://libproxy.txstate.edu/login?url=http://search.ebscohost.com/login.aspx?direct= true \&db=nlebk\&AN=24383\&site=eds-live\&scope $=$ site (accessed on 5 March 2016).

16. Agdas, D.; Srinivasan, R.S.; Frost, K.; Masters, F.J. Energy use assessment of educational buildings: Toward a campus-wide sustainable energy policy. Sustain. Cities Soc. 2015, 17, 15-21. [CrossRef]

17. EPA. Universities, Colleges Not Receiving Top Marks for Environmental Compliance; No. 300-N-00-012; EPA: Washington, DC, USA, 2000.

18. Savely, S.M.; Carson, A.I.; Delclos, G.L. An environmental management system implementation model for US colleges and universities. J. Clean. Prod. 2007, 15, 660-670. [CrossRef] 
19. Cortese, A. Education for Sustainability: The Need for a New Human Perspective; Opinion Paper; Second Nature, Inc.: Boston, MA, USA, 1999.

20. Junyent, M.; Ciurana, A.M.G. Education for sustainability in university studies: A model for reorienting the curriculum. Br. Educ. Res. J. 2008, 34, 763-782. [CrossRef]

21. Sterling, S. (Ed.) Sustainability Education: Perspectives and Practice across Higher Education, 1st ed.; Earthscan, Taylor \& Francis: New York, NY, USA, 2010.

22. Viebahn, P. An environmental management model for universities: From environmental guidelines to staff involvement. J. Clean. Prod. 2002, 10, 3-12. [CrossRef]

23. Pullen, S. Energy Assessment of Institutional Buildings. Ph.D. Thesis, Adelaide University and ANZAScA, Adelaide, Australia, 2000.

24. Swearingen White, S. Campus sustainability plans in the United States: Where, what, and how to evaluate? Int. J. Sustain. High. Educ. 2014, 15, 228-241. [CrossRef]

25. Johnston, L.F. (Ed.) Higher Education for Sustainability: Cases, Challenges, and Opportunities from across the Curriculum, 1st ed.; Routledge: New York, NY, USA, 2013; ISBN 978-0-415-51935-9.

26. Sheri, L. Sustainable Stewardship, Actions to Improve Campus Energy Efficiency; Texas State University: San Marcos, TX, USA, 2016.

27. Velazquez, L.; Munguia, N.; Platt, A.; Taddei, J. Sustainable university: What can be the matter? J. Clean. Prod. 2006, 14, 810-819. [CrossRef]

28. Weaver, R. Critical sustainabilities: Negotiating sustainability's discursive maze in the classroom. J. Geogr. 2015, 114, 223-234. [CrossRef]

29. WCED. World Commission on Environment and Development, Bruntland Commission, Our Common Future. Report of the World Commission on Environment and Development; 1987. Available online: http:/ / mom.gov.af/Content/ files/Bruntland_Report.pdf (accessed on 9 June 2018).

30. Portney, K.E. Sustainability, 1st ed.; The MIT Press: Cambridge, MA, USA; London, UK, 2015; ISBN 978-0-262-52850-4.

31. Daly, H.E.; Cobb, J.B.; Cobb, C.W. For the Common Good: Redirecting the Economy toward Community, the Environment, and a Sustainable Future, 2nd ed.; Beacon Press: Boston, MA, USA, 1994; ISBN 0-8070-4705-8.

32. Norton, B.G. Sustainability: A Philosophy of Adaptive Ecosystem Management, 1st ed.; University of Chicago Press: Chicago, IL, USA, 2005; ISBN 0-226-59521-8. Available online: http:/ /libproxy.txstate.edu/login?url= http:/ / search.ebscohost.com/login.aspx?direct=true\&db=nlebk\&AN=349592\&site=eds-live\&scope=site (accessed on 7 September 2018).

33. Agyeman, J. Introducing Just Sustainabilities: Policy, Planning, and Practice, 1st ed.; Zed Books Ltd.: New York, NY, USA, 2013; ISBN 978-1-78032-410-4.

34. Grindsted, T.S. Sustainable universities-from declarations on sustainability in higher education to national law. Environ. Econ. 2011, 2. [CrossRef]

35. Clarke, A.; Kouri, R. Choosing an appropriate university or college environmental management system. J. Clean. Prod. 2009, 17, 971-984. [CrossRef]

36. Suwartha, N.; Sari, R.F. Evaluating UI GreenMetric as a tool to support green universities development: Assessment of the year 2011 ranking. J. Clean. Prod. 2013, 61, 46-53. [CrossRef]

37. Steger, U. Environmental management systems: Empirical evidence and further perspectives. Eur. Manag. J. 2000, 18, 23-37. [CrossRef]

38. Dixon, D.; McMordie, K. Energy Efficiency Assessment Methods and Tools Evaluation; Association of Energy Engineers: Atlanta, GA, USA, 1995.

39. Kozman, T.A.; Aulds, B.N.; Lee, J. Energy assessment and conservation, in a university environment. Energy Eng. 2011, 108, 54-62. [CrossRef]

40. Costanza, R. Embodied energy and economic valuation. Science 1980, 210, 1219-1224. [CrossRef] [PubMed]

41. Zhao, H.; Magoulès, F. A review on the prediction of building energy consumption. Renew. Sustain. Energy Rev. 2012, 16, 3586-3592. [CrossRef]

42. Boza-Kiss, B.; Moles-Grueso, S.; Urge-Vorsatz, D. Evaluating policy instruments to foster energy efficiency for the sustainable transformation of buildings. Curr. Opin. Environ. Sustain. 2013, 5, 163-176. [CrossRef]

43. Sightlines. The State of Facilities in Higher Education. 2015. Benchmark, Best Practices, and Trends. Available online: https: / /www.sightlines.com/insight/state-of-facilities-2015 (accessed on 9 June 2016). 
44. Pérez-Lombard, L.; Ortiz, J.; Pout, C. A review on buildings energy consumption information. Energy Build. 2008, 40, 394-398. [CrossRef]

45. Conti, J.; Holtberg, P.; Diefenderfer, J.; LaRose, A.; Turnure, J.T.; Westfall, L. International Energy Outlook 2016 with Projections to 2040; No. DOE/EIA-0484; Office of Energy Analysis; USDOE Energy Information Administration (EIA): Washington, DC, USA, 2016.

46. Goldman, S.; Ungar, L.; Capanna, S.; Simchak, T. Energy Efficiency: A Tool for Climate Change Adaptation. Technical Report February. Alliance to Save Energy, 2012. Available online: https:/ /www.ase.org/sites/ase. org/files/ASE-EE_A_Tool_For_Climate_Change_Adaptation.pdf (accessed on 10 August 2016).

47. Tol, R.S.J. The economic effects of climate change. J. Econ. Perspect. 2009, 23, 29-51. [CrossRef]

48. Yearbook, Global Energy Statistical. Electricity Domestic Consumption. Available online: https: / / yearbook.enerdata.net/world-electricity-production-map-graph-and-data.html\#electricitydomesticconsumption-data-by-region (accessed on 20 October 2016).

49. United Nations. Sustainable Development Goals; United Nations: New York, NY, USA, 2015.

50. Obama, B. The irreversible momentum of clean energy. Science 2017, 355, 126-129. [CrossRef] [PubMed]

51. NewYorkMagazine, Daily Intelligencer. Available online: http://nymag.com/daily/intelligencer/2017/03/ doe-climate-office-bans-use-of-phrase-climate-change.html (accessed on 6 September 2018).

52. Brown, M.A.; Gumerman, E.; Sun, X.; Baek, Y.; Wang, J.; Cortes, R.; Soumonni, D. Energy Efficiency in the South; Atlanta, Southeast Energy Efficiency Alliance: Atlanta, GA, USA, 2010.

53. Team, C.W.; Pachauri, R.K.; Meyer, L.A. IPCC: Climate Change 2014: Synthesis Report; Contribution of Working Groups I, II and III to the Fifth Assessment Report of the Intergovernmental Panel on Climate Change; IPCC: Geneva, Switzerland, 2014; Volume 151.

54. Saidur, R. A review on electrical motors energy use and energy savings. Renew. Sustain. Energy Rev. 2010, 14, 877-898. [CrossRef]

55. Fatih, B. World Energy Outlook; Organization for Economic Co-Operation and Development (OECD): Paris, France, 2015.

56. The Washington Post. Threatened by Climate Change Florida Reportedly Bans Term 'Climate Change'. Available online: https:/ / www.washingtonpost.com/news/morning-mix/wp/2015/03/09/florida-statemost-affected-by-climate-change-reportedly-bans-term-climate-change $/$ ?noredirect=on\&utm_term= .0c27ae6748a3 (accessed on 9 June 2018). 